\title{
Implementasi Recurrent Neural Network dalam Memprediksi Kepadatan Restoran Berbasis LSTM
}

\author{
Annisa Farhah*, Anggunmeka Luhur Prasasti, Marisa W Paryasto \\ Fakultas Teknik Elektro, Prodi S1 Teknik Komputer, Telkom University, Bandung, Indonesia \\ Email: 1,*annisafrhh@student.telkomuniversity.ac.id, ${ }^{2}$ anggunmeka@telkomuniversity.ac.id, \\ ${ }^{3}$ marisaparyasto@telkomuniversity.ac.id \\ Email Penulis Korespondensi: annisafrhh@student.telkomuniversity.ac.id
}

\begin{abstract}
Abstrak-Di zaman modern ini, restoran menjadi sangat populer, terutama di kota-kota besar. Namun, hal ini dapat menyebabkan kepadatan atau antrian pengunjung di restoran, hal tersebut harus dihindari selama pandemi Covid-19 saat ini. Sehingga informasi akurat yang dapat memprediksi kepadatan restoran akan sangat bermanfaat. Dalam memprediksi kepadatan restoran, dilakukan pengolahan data jumlah pengunjung yang didapat dari salah satu restoran dengan menggunakan kecerdasan buatan berupa LSTM (Long Short Term Memory) RNN (Recurrent Neural Network). Hasil penelitian Recurrent Neural Network berbasis LSTM (Long Short Term Memory) pada parameter learning rate terbaik 0,001 dan epoch maksimum 2000 menghasilkan nilai MSE sebesar 0,000000278 pada data latih dan 0,0069 pada data uji.
\end{abstract}

Kata Kunci: Prediksi; Recurrent Neural Network; Long Short Term Memory

Abstract- In this modern era, restaurants are becoming very popular, especially in big cities. However, this can lead to density or queues of visitors at a restaurant, which should be avoided during the current Covid-19 pandemic. So that accurate information that can predict the density of restaurant will be very useful. In predicting the density of restaurants, data processing on the number of visitors obtained from one of the restaurants is carried out using artificial intelligence in the form of LSTM (Long Short Term Memory) RNN (Recurrent Neural Network). The results of the research on Recurrent Neural Network based on LSTM (Long Short Term Memory) at the best learning rate parameter of 0.001 and a maximum epoch of 2000 resulted in an MSE value of 0.00000278 on the training data and 0.0069 on the test data.

Keywords: Prediction; Recurrent Neural Network; Long Short Term Memory

\section{PENDAHULUAN}

Di zaman modern ini, banyak bermunculan tempat makan berupa restoran. Munculnya restoran ini sangat marak terutama di daerah kota besar. Restoran yang bermunculan banyak mengundang daya tarik masyarakat khususnya yang menyukai makanan cepat saji. Akibatnya, kemunculan restoran akan semakin banyak mengundang daya tarik masyarakat yang dapat mengakibatkan kepadatan dan antrian pengunjung. Sedangkan berdasarkan aturan pemerintah saat ini mengharuskan masyarakat menjaga jarak dan menjauhi kerumunan yang memiliki tujuan untuk memutus rantai penularan virus covid-19[1]

Selain kualitas pelayanan restoran yang harus ditingkatkan dan menerapkan protokol kesehatan, berbagai solusi saat ini banyak ditawarkan oleh beberapa restoran seperti memanfaatkan layanan makanan pesan antar secara online sehingga pengunjung tidak perlu repot-repot mengunjungi restoran secara langsung, Namun terkadang layanan ini memiliki estimasi waktu yang cukup lama dan tidak sesuai perkiraan. Sehingga Informasi yang akurat, tepat pada waktunya serta relevan[2] dalam memprediksi kepadatan pengunjung menjadi lebih penting agar pengunjung dapat dengan mudah mengetahui keadaan suatu restoran dan dapat memutuskan restoran mana yang akan dituju.

Proses memprediksi secara terstruktur kejadian di masa datang bersumber pada data informasi yang pernah terjadi di masa lampau dengan mempertimbangkan masa kini guna meminimalisir penyimpangan antara data perkiraan yang dihasilkan dengan keterjadian merupakan pengertian dari prediksi[3]. Adapun pendekatan yang digunakan dalam memprediksi yaitu berupa pendekatan time-series dan pendekatan cause-effects method [4]. Pada pendekatan time-series menjelaskan bahwa model dipengaruhi oleh data yang terjadi pada masa lampau. Sedangkan pendekatan yang menunjukkan keadaan sebab akibat yang terjadi oleh hal tertentu merupakan penjelasan dari pendekatan cause-effects method.

Pada dasarnya upaya untuk meniru fungsi otak manusia dengan model komputer[5], dan umumnya ini melibatkan sebuah neuron yang saling terhubung satu sama lain dalam memproses setiap informasi yang masuk dari neuron satu ke neuron yang lain untuk menghasilkan keluaran berupa informasi yang dibutuhkan merupakan pengertian dari Jaringan saraf tiruan atau neural network. Neural network memiliki banyak jenis arsitektur, salah satunya adalah Recurrent Neural Network (RNN) yang menerapkan data sekuensial pada arsitekturnya. RNN mempunyai kelebihan dalam memproses data yang masuk secara berulang-ulang membentuk sebuah time series [6]. Pada RNN setiap output dari hidden layer akan mengalami looping ke dirinya sendiri, begitu seterusnya sehingga memperoleh hasil output yang paling akurat. Sehingga jaringan RNN dapat mengeksploitasi informasi di masa lalu untuk meramalkan data di masa mendatang yang cocok dalam memprediksi suatu keadaan. Secara konseptual menyatakan bahwasanya RNN mempunyai daya ingat memori terhadap kejadian yang pernah terjadi sebelumnya[6], namun hal tersebut sulit jika dilakukan untuk memiliki sekuens yang panjang. RNN akan menggunakan LSTM untuk mengatasi masalah ketergantungan jangka panjang tersebut dengan memberikan sebuah "gerbang" memori ke dalam sel pada hidden layer[7]. Fungsi mengatur memori pada setiap neurons 
merupakan bagian dari memory cells dan gate units pada LSTM. Pada cell akan diberikan input dari hidden layer sebelumnya (ht-1) dan input saat ini (xt) untuk menghitung hidden layer berikutnya. Pada LSTM terdapat 3 gates unit yaitu forget gates, input gates, dan output gates[8].

Penelitian dengan metode Recurrent Neural Network Long Short Term Memory (RNN LSTM) untuk memprediksi kunjungan wisatawan dilakukan[9] dengan merancang dataset kunjungan wisatawan setiap bulan menjadi sebuah time series dimana terdapat adanya suatu pengamatan historis $(\mathrm{t}-1, \mathrm{t}-2, \ldots \mathrm{t}-\mathrm{n})$ dan ramalan $\mathrm{t}, \mathrm{t}+1$ dan $\mathrm{t}+2$.

Penelitian lain mengenai Recurrent Neural Network yang menerapkan LSTM dilakukan[10]. Tujuan penelitian tersebut untuk memprediksi arus lalu lintas pada Intelligent Transportation System (ITS). Hasil eksperimen menunjukkan bahwa metode pembelajaran mendalam berbasis Recurrent Neural Network (RNN) seperti LSTM mempunyai kinerja lebih baik dibandingkan dengan metode lain seperti ARIMA. Hal tersebut dikarenakan prediksi arus lalu lintas yang bersifat stokastik lebih membutuhkan model jaringan nonlinier dibandingkan model linier.

Penelitian yang berhubungan dengan kepadatan dijelaskan[11] mengenai kuantitas atau jumlah penduduk yang dapat berpotensi menimbulkan kepadatan di suatu wilayah. Hal tersebut erat kaitannya jika dihubungkan dengan kepadatan di suatu restoran yang dipengaruhi oleh jumlah pengunjung dan kapasitas yang dimiliki restoran. Karena pada dasarnya kepadatan penduduk dapat diartikan hasil suatu pembagian jumlah penduduk dengan luas wilayah yang ditempati[12]. Penelitian[13] masih berhubungan dengan faktor penyebab kepadatan yang dijelaskan pada ruas jalan, dimana kepadatan lalu lintas dapat dilihat berdasarkan volume kendaraan dan kecepatan. Pada kepadatan restoran juga terdapat dua faktor yang hampir sama dengan penelitian tersebut yaitu jumlah pengunjung dan waktu rata-rata setiap pengunjung yang datang.

Sebagaimana pada penelitian[14] menyatakan bahwa pada penerapan prediksi dengan metode RNN lainnya seperti menggunakan Elman Recurrent Neural Network (ERNN) guna memprediksi tingkat suatu penjualan dari sebuah produk pilus merupakan salah satu upaya perusahaan agar dapat menimalisir terjadinya kerugian. Pada dataset dilakukan partisi data training serta data testing yang mana perbandingan dilakukan sebesar 70\%:30\%, 80\%:20\%, dan 90\%:10\%. Dalam penelitian tersebut terdapat beberapa tolak ukur yang digunakan berupa maksimal epoch sebesar 500, nilai learning rate sebesar 0.1 s.d 0.9, serta jumlah neuron sebanyak 5 neuron pada input layer, 7 pada hidden layer dan menghasilkan 1 output. Sehingga menghasilkan akurasi terbaik dengan metode ERNN sebesar $90.25 \%$.

Pada penelitian [15] terkait prediksi dengan Neural Network dan menerapkan Extended Kalman Filter (EKF) dilakukan terhadap proses training data. Penerapan EKF mampu memecahkan masalah data yang harus di proses secara non-stationer. Penelitian lain menggunakan EKF [16] mengenai prediksi terjadinya banjir, menghasilkan akurasi terbaik terhadap model yang telah dibuat.

Pada penelitian ini mencoba mendapatkan informasi mengenai kepadatan suatu restoran dengan membangun sebuah sistem kecerdasan buatan berupa Recurrent Neural Network berbasis LSTM untuk mengolah data pengunjung yang dapat menghasilkan prediksi keadaan pengunjung di suatu restoran.

\section{METODOLOGI PENELITIAN}

\subsection{Pemodelan Sistem Kepadatan Restoran}

Sistem Kepadatan Restoran di bangun menggunakan bahasa pemrograman python dengan menggunakan modul pyrebase sebagai penghubung sistem ke database aplikasi, dan modul numpy untuk mempermudah perhitungan dalam sistem. Serta di bangun menggunakan arsitektur Recurrent Neural Network berbasis LSTM yang sesuai untuk pemrosesan rangkaian waktu pada dataset yang digunakan. Adapun strategi sistem yang dibangun dimulai dari tahap preprocessing data, inisialisasi parameter, training RNN LSTM, serta melakukan pengujian terhadap data testing. Berikut adalah alur pada sistem yang berkerja dapat dilihat pada gambar 1.

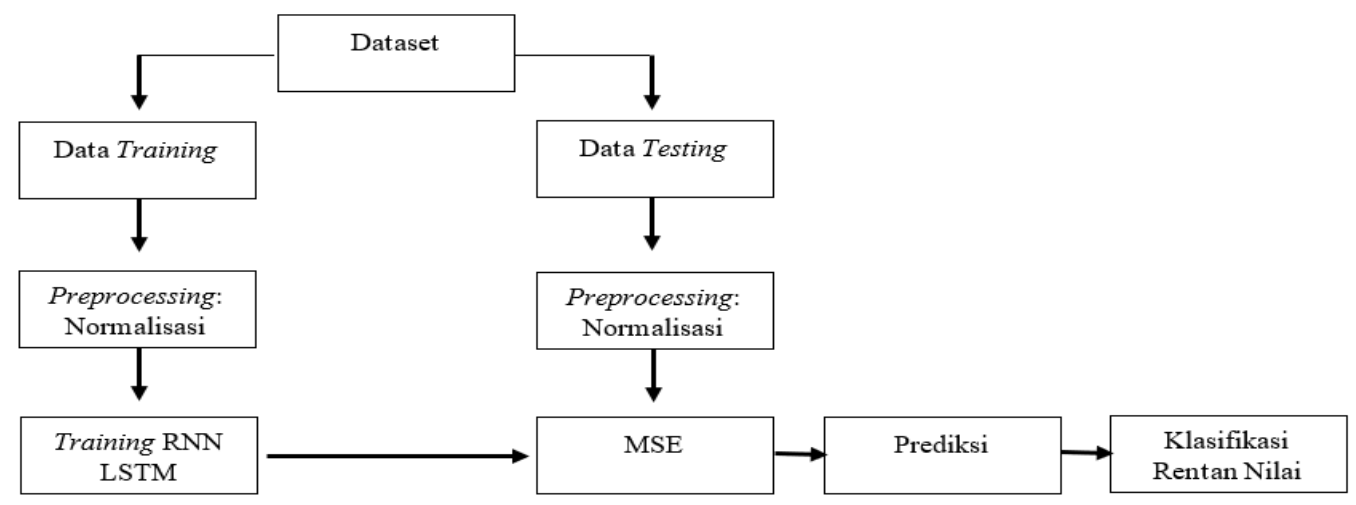

Gambar 1. Alur Kerja 
Pada Gambar 1. menjelaskan proses alur kerja sistem dimulai dari membagi dataset menjadi data training dan data testing dengan persentase pembagian yang telah ditentukan. Kemudian data training dan testing akan dinormalisasi menggunakan min-max scaling dengan mengubah data kedalam range [0,1]. Pada data training akan dilakukan pembelajaran terlebih dahulu dengan sistem yang dibangun sebelum dilakukan pehitungan eror menggunakan MSE. Tahap selanjutnya, setelah mendapatkan selisih eror terbaik pada data maka hasil prediksi akan diklasifikasikan menggunakan rentan nilai yang ditentukan.

\subsubsection{Preprocessing Data}

Dataset diperoleh dari suatu restoran xx yang menunjukkan jumlah pengunjung di restoran xx terhitung dari pukul 07.00 s.d 21.00 WIB dimulai dari hari Senin s.d Minggu bulan Januari - Februari tahun 2020 dengan total data 210 baris. Dari total dataset yang ada, dilakukan preprocessing data dengan membagi data antara data train dan data test. berikutnya, dilakukan normalisasi data. Berikut ini adalah persentase pembagian data yang digunakan dapat dilihat pada tabel 1.

Tabel 1. Persentase Partisi Data

\begin{tabular}{cc}
\hline Data Training & Data Testing \\
\hline $50 \%$ & $50 \%$ \\
105 Data & 105 Data \\
\hline
\end{tabular}

Dalam meminimalisir tingkat kesalahan atau eror, maka perlu melakukan normalisasi terlebih dahulu pada dataset train dan data test dengan cara mengubah data kedalam range [0,1] serta teknik yang digunakan berupa normalisasi min-max scaling. Berikut adalah rumus normalisasi min-max scaling:

$$
X^{\prime}=\frac{\left(\mathrm{X}-\min _{\mathrm{x}}\right)}{\left(\max _{\mathrm{x}}-\min _{\mathrm{x}}\right)}
$$

$\mathrm{X}^{\prime} \quad=$ data hasil normalisasi

$\mathrm{X} \quad=$ data actual

$\max _{\mathrm{x}}=$ nilai maksimal dari data input

$\min _{\mathrm{x}}=$ nilai minimal dari data input

\subsubsection{Inisialisasi Parameter}

Inisialisasi parameter yang dibutuhkan pada metode Recurent Neural Network berbasis LSTM adalah nilai learning rate, nilai epoch maksimum, fungsi aktivasi, serta model yang dibangun. Besarnya nilai learning rate yang akan diuji adalah 0.9,0.6, 0.3, 0.1, 0.01, dan 0.001 dengan maksimum epoch 2000. Dalam memilih nilai learning rate tersebut akan membuat proses pembelajaran data dengan metode RNN berbasis LSTM berjalan lebih baik. Fungsi aktivasi yang digunakan pada output layer merupakan fungsi aktivasi RelU (Rectified Linear Unit) karena merupakan function yang memiliki range [0 sampai takhingga). Berikut adalah rumus dari fungsi aktivasi RelU:

$$
\operatorname{RelU}(x)=\max (0, x)
$$

Model yang dibangun menggunakan RNN berbasis LSTM dibuat berdasarkan time series. Dimana terdapat data masa lalu ( $\mathrm{t}-1$ dan $\mathrm{t}-2)$, dan data prediksi $(\mathrm{t}, \mathrm{t}+1)$. Adapun beberapa parameter yang akan dibangun sehingga dapat mempengaruhi hasil ouput yang ditunjukkan pada tabel berikut:

Tabel 2. Model RNN LSTM

\begin{tabular}{cc}
\hline Parameter & Jumlah \\
\hline Total layer & 5 layer \\
Input layer & 128 neuron \\
Hidden layer & 3 layer dengan 128 dan 64 neuron \\
Output layer & 1 neuron \\
\hline
\end{tabular}

\subsubsection{Training RNN LSTM}

Proses training data dilakukan setelah melalui tahap preproccesing data sebanyak nilai epoch yang telah ditentukan hingga menghasilkan hasil yang paling optimal. Jika belum, maka dilakukan optimasi dengan learning rate yang telah ditentukan. Kemudian akan memperbarui bobot dan bias pada sistem. Proses terakhir dilakukan perhitungan eror menggunakan MSE (Mean Square Error) dengan membandingkan data training terhadap data real dengan persamaan:

$$
M S E=f(z)=\frac{1}{N} \sum_{i=1}^{N}(f i-y i)^{2}
$$


JURNAL MEDIA INFORMATIKA BUDIDARMA

Volume 5, Nomor 2, April 2021, Page 524-531

ISSN 2614-5278 (media cetak), ISSN 2548-8368 (media online)

Available Online at https://ejurnal.stmik-budidarma.ac.id/index.php/mib

DOI 10.30865/mib.v5i2.2916

\subsubsection{Uji Terhadap Data Testing}

Setelah didapatkan hasil dari proses training pada data training, kemudian dilakukan pengujian terhadap data testing yang didapat dari tahap preprocessing dengan menggunakan perhitungan MSE pada permasaan (3), dimana data testing akan dibandingkan dengan data real.

\subsection{Skenario Pengujian Parameter Metode Recurrent Neural Network}

Skenario Pengujian ini berfungsi untuk mengetahui apakah sistem ini dapat mengukur performansi model yang telah dibangun. Maka dari itu dilakukan pengujian dengan parameter yang ada. Parameter tersebut diantaranya mengubah nilai learning rate dan mengubah nilai epoch hingga mendapatkan bobot yang paling ideal. Berikut menunjukkan skenario untuk parameter learning rate dan epoch yang akan diuji:

\subsubsection{Parameter Learning Rate}

Pada skenario pengujian leraning rate menggunakan nilai epoch 2000 dengan skenario yang ditunjukkan pada tabel berikut:

Tabel 3. Skenario Pengujian Learning Rate

\begin{tabular}{cccc}
\hline Pengujian Epoch & Partisi Data & Learning Rate & Epoch \\
\hline Pertama & & 0.9 & \\
Kedua & & 0.6 & \\
Ketiga & $50 \%: 50 \%$ & 0.3 & 2000 \\
Keempat & & 0.1 & \\
Kelima & & 0.01 & \\
Keenam & & 0.001 & \\
\hline
\end{tabular}

Pada tabel 3 dapat dilihat bahwa pengujian learning rate dilakukan sebanyak enam kali dengan nilai yang berbeda-beda serta nilai epoch yang sudah ditentukan yaitu 2000.

\subsubsection{Parameter Epoch}

Pada skenario pengujian epoch ini akan menggunakan nilai pengujian learning rate yang menghasilkan selisih nilai MSE terkecil. Skenario epoch ditunjukkan pada table berikut:

Tabel 4. Skenario Pengujian Epoch

\begin{tabular}{cccc}
\hline Pengujian Epoch & Partisi Data & Learning Rate & Epoch \\
\hline Pertama & & & 100 \\
Kedua & & Menggunakan & 500 \\
Ketiga & $50 \%: 50 \%$ & learning rate dengan & 1000 \\
Keempat & & selisih MSE terkecil & 1500 \\
Kelima & & & 200 \\
\hline
\end{tabular}

Pada tabel 4. dapat dilihat bahwa pengujian epoch yang dilakukan sebanyak lima kali percobaan dengan nilai epoch yang berbeda-beda.

\section{HASIL DAN PEMBAHASAN}

\subsection{Hasil Pengujian Parameter Metode Recurrent Neural Network}

Dari scenario yang telah dibuat maka pengujian dilakukan dengan nilai learning rate dan epoch yang sudah ditentukkan.

\subsubsection{Pengujian Parameter Learning Rate}

Untuk melihat selisih nilai MSE terbaik dilakukan pengujian ini terhadap parameter learning rate dengan merujuk pada tabel 2 .

a. Pengujian Learning Rate Pertama

Pada pengujian pertama akan menggunakan partisi data sebesar $50 \%$ data train dan $50 \%$ data test, nilai learning rate sebesar $\alpha=0.9$ dan nilai epoch sebesar 2000.

b. Pengujian Learning Rate Kedua

Pada pengujian kedua akan menggunakan partisi data sebesar $50 \%$ data train dan $50 \%$ data test, nilai learning rate sebesar $\alpha=0.6$ dan nilai epoch sebesar 2000 .

c. Pengujian Learning Rate ketiga

Pada pengujian ketiga akan menggunakan partisi data sebesar $50 \%$ data train dan $50 \%$ data test, nilai learning rate sebesar $\alpha=0.3$ dan nilai epoch sebesar 2000 . 


\section{JURNAL MEDIA INFORMATIKA BUDIDARMA}

Volume 5, Nomor 2, April 2021, Page 524-531

ISSN 2614-5278 (media cetak), ISSN 2548-8368 (media online)

Available Online at https://ejurnal.stmik-budidarma.ac.id/index.php/mib

DOI 10.30865/mib.v5i2.2916

d. Pengujian Learning Rate Keempat

Pada pengujian keempat akan menggunakan partisi data sebesar $50 \%$ data train dan $50 \%$ data test, nilai learning rate sebesar $\alpha=0.1$ dan nilai epoch sebesar 2000 .

e. Pengujian Learning Rate kelima

Pada pengujian kelima akan menggunakan partisi data sebesar 50\% data train dan $50 \%$ data test, nilai learning rate sebesar $\alpha=0.01$ dan nilai epoch sebesar 2000 .

f. Pengujian Learning Rate Keenam

Pada pengujian pertama akan menggunakan partisi data sebesar $50 \%$ data train dan $50 \%$ data test, nilai learning rate sebesar $\alpha=0.001$ dan nilai epoch sebesar 2000 .

Dari hasil pengujian learning rate pertama sampai pengujian keenam dapat dibuat tabel nilai MSE dengan hasil perbandingan data train : real dan data test : real berikut:

Tabel 5. Hasil Pengujian Learning Rate

\begin{tabular}{ccccc}
\hline Pengujian Epoch & $\begin{array}{c}\text { Learning } \\
\text { Rate }\end{array}$ & Epoch & $\begin{array}{c}\text { MSE } \\
\text { Train }: \text { Real }\end{array}$ & $\begin{array}{c}\text { MSE } \\
\text { Test }: \text { Real }\end{array}$ \\
\hline Pertama & 0.9 & & 0,0061 & 0.0054 \\
Kedua & 0.6 & & 0,012 & 0.012 \\
Ketiga & 0.3 & 2000 & 0,0063 & 0.0054 \\
Keempat & 0.1 & & 0,0061 & 0.0054 \\
Kelima & 0.01 & 0,0029 & 0.005 \\
Keenam & 0.001 & & 0,000000278 & 0.0069 \\
\hline
\end{tabular}

Berdasarkan Tabel 5. dihasilkan nilai learning rate terbaik saat data dilatih pada pengujian keenam sebesar 0.001 menghasilkan nilai MSE terkecil yaitu 0.000000278 dengan nilai MSE data test 0.0069. Dari hasil tersebut menunjukkan bahwa semakin kecil nilai learning rate maka semakin baik nilai MSE yang diperoleh[17]. Karena data real memiliki range nilai dari 0-1 maka learning rate terbaik yaitu saat nilai MSE semakin mendekati nol (0).

\subsubsection{Pengujian Parameter Epoch}

Berdasarkan perolehan selisih nilai MSE terkecil pada pengujian learning rate, maka pengujian dilakukan kembali dengan parameter epoch untuk melihat kembali apakah terdapat perubahan nilai MSE dengan merujuk pada tabel 3.

a. Pengujian Epoch Pertama

Pada pengujian pertama akan menggunakan partisi data sebesar $50 \%$ data train dan $50 \%$ data test, nilai learning rate sebesar $\alpha=0.001$ dan nilai epoch sebesar 100 .

b. Pengujian Epoch Kedua

Pada pengujian kedua akan menggunakan partisi data sebesar $50 \%$ data train dan $50 \%$ data test, nilai learning rate sebesar $\alpha=0.001$ dan nilai epoch sebesar 500 .

c. Pengujian Epoch ketiga

Pada pengujian ketiga akan menggunakan partisi data sebesar $50 \%$ data train dan $50 \%$ data test, nilai learning rate sebesar $\alpha=0.001$ dan nilai epoch sebesar 1000 .

d. Pengujian Epoch Keempat

Pada pengujian keempat akan menggunakan partisi data sebesar $50 \%$ data train dan $50 \%$ data test, nilai learning rate sebesar $\alpha=0.001$ dan nilai epoch sebesar 1500 .

e. Pengujian Epoch kelima

Pada pengujian kelima akan menggunakan partisi data sebesar $50 \%$ data train dan $50 \%$ data test, nilai learning rate sebesar $\alpha=0.001$ dan nilai epoch sebesar 2000 .

Dari pengujian epoch pertama hingga kelima telah dibuat tabel yang menunjukkan hasil perbandingan nilai MSE pada data train : real dan data test : real berikut:

Tabel 6. Skenario Pengujian Epoch

\begin{tabular}{ccccc}
\hline Pengujian Epoch & Epoch & Learning Rate & $\begin{array}{c}\text { MSE } \\
\text { Train }: \text { Real }\end{array}$ & $\begin{array}{c}\text { MSE } \\
\text { Test }: \text { Real }\end{array}$ \\
\hline Pertama & 100 & & 0.0034 & 0.006 \\
Kedua & 500 & & 0.00016 & 0.006 \\
Ketiga & 1000 & 0,001 & 0.000025 & 0.007 \\
Keempat & 1500 & & 0.00013 & 0.007 \\
Kelima & 2000 & & 0.00000064 & 0.007 \\
\hline
\end{tabular}

Berdasarkan Tabel 6. nilai MSE terbaik berada pada epoch 2000 untuk data train : real karena menghasilkan nilai MSE terkecil sebesar 0.00000064 dengan nilai MSE data test : real sebesar 0.007. 
Sehingga dari penelitian tersebut dapat diambil kesimpulan bahwa dengan menggunakan metode Recurrent Neural Network berbasis LSTM menghasilkan selisih eror MSE yang lebih baik sebesar 2.78E-07 pada data latih dan 0.0069 pada data uji jika dibandingkan dengan penelitian [18] menyatakan bahwa hasil menggunakan metode Feedforward Neural Network menghasilkan nilai MSE 7.585E-06 pada data latih dan 0.006923 pada data uji.

\subsection{Hasil Pengujian Sistem Prediksi Kepadatan Restoran}

Setelah melakukan training pada dataset dengan membangun model RNN LSTM, maka akan menghasilkan prediksi kepadatan restoran. Tabel 7 menunjukkan perbandingan antara persentase data real dengan hasil output prediksi sebagai berikut:

Tabel 7. Persentase Perbandingan Data Real dengan Prediksi Kepadatan Restoran

\begin{tabular}{|c|c|c|c|c|c|c|c|c|c|c|c|c|c|c|}
\hline \multirow{2}{*}{ Jam/Hari } & \multicolumn{2}{|c|}{ Senin } & \multicolumn{2}{|c|}{ Selasa } & \multicolumn{2}{|c|}{ Rabu } & \multicolumn{2}{|c|}{ Kamis } & \multicolumn{2}{|c|}{ Jum'at } & \multicolumn{2}{|c|}{ Sabtu } & \multicolumn{2}{|c|}{ Minggu } \\
\hline & DR & HP & DR & HP & DR & HP & DR & HP & DR & HP & DR & HP & DR & HP \\
\hline 07:00:00 & $5 \%$ & $5 \%$ & $3 \%$ & $3 \%$ & $13 \%$ & $13 \%$ & $6 \%$ & $6 \%$ & $15 \%$ & $15 \%$ & $8 \%$ & $8 \%$ & $8 \%$ & $8 \%$ \\
\hline 08:00:00 & $2 \%$ & $2 \%$ & $14 \%$ & $14 \%$ & $34 \%$ & $34 \%$ & $13 \%$ & $13 \%$ & $12 \%$ & $12 \%$ & $17 \%$ & $17 \%$ & $4 \%$ & $4 \%$ \\
\hline 09:00:00 & $8 \%$ & $8 \%$ & $5 \%$ & $5 \%$ & $1 \%$ & $1 \%$ & $5 \%$ & $5 \%$ & $8 \%$ & $8 \%$ & $5 \%$ & $5 \%$ & $10 \%$ & $10 \%$ \\
\hline 10:00:00 & $10 \%$ & $10 \%$ & $4 \%$ & $4 \%$ & $15 \%$ & $15 \%$ & $16 \%$ & $16 \%$ & $12 \%$ & $12 \%$ & $8 \%$ & $8 \%$ & $19 \%$ & $19 \%$ \\
\hline 11:00:00 & $29 \%$ & $29 \%$ & $14 \%$ & $14 \%$ & $24 \%$ & $24 \%$ & $22 \%$ & $22 \%$ & $12 \%$ & $12 \%$ & $3 \%$ & $3 \%$ & $6 \%$ & $6 \%$ \\
\hline 12:00:00 & $22 \%$ & $22 \%$ & $19 \%$ & $18 \%$ & $27 \%$ & $27 \%$ & $34 \%$ & $34 \%$ & $37 \%$ & $37 \%$ & $16 \%$ & $16 \%$ & $9 \%$ & $9 \%$ \\
\hline 13:00:00 & $13 \%$ & $13 \%$ & $6 \%$ & $6 \%$ & $11 \%$ & $11 \%$ & $11 \%$ & $11 \%$ & $19 \%$ & $19 \%$ & $4 \%$ & $4 \%$ & $6 \%$ & $6 \%$ \\
\hline 14:00:00 & $7 \%$ & $7 \%$ & $4 \%$ & $4 \%$ & $13 \%$ & $13 \%$ & $12 \%$ & $12 \%$ & $7 \%$ & $7 \%$ & $5 \%$ & $5 \%$ & $6 \%$ & $6 \%$ \\
\hline 15:00:00 & $13 \%$ & $12 \%$ & $9 \%$ & $9 \%$ & $8 \%$ & $8 \%$ & $10 \%$ & $10 \%$ & $13 \%$ & $13 \%$ & $4 \%$ & $4 \%$ & $5 \%$ & $5 \%$ \\
\hline 16:00:00 & $3 \%$ & $3 \%$ & $4 \%$ & $4 \%$ & $7 \%$ & $7 \%$ & $4 \%$ & $4 \%$ & $9 \%$ & $9 \%$ & $13 \%$ & $13 \%$ & $10 \%$ & $10 \%$ \\
\hline 17:00:00 & $20 \%$ & $20 \%$ & $20 \%$ & $20 \%$ & $36 \%$ & $36 \%$ & $13 \%$ & $13 \%$ & $8 \%$ & $8 \%$ & $16 \%$ & $16 \%$ & $7 \%$ & $7 \%$ \\
\hline 18:00:00 & $10 \%$ & $10 \%$ & $9 \%$ & $9 \%$ & $8 \%$ & $8 \%$ & $5 \%$ & $5 \%$ & $10 \%$ & $10 \%$ & $9 \%$ & $9 \%$ & $9 \%$ & $9 \%$ \\
\hline 19:00:00 & $0 \%$ & $0 \%$ & $10 \%$ & $10 \%$ & $18 \%$ & $18 \%$ & $20 \%$ & $20 \%$ & $13 \%$ & $13 \%$ & $5 \%$ & $5 \%$ & $7 \%$ & $7 \%$ \\
\hline 20:00:00 & $15 \%$ & $15 \%$ & $6 \%$ & $6 \%$ & $21 \%$ & $21 \%$ & $26 \%$ & $26 \%$ & $19 \%$ & $19 \%$ & $13 \%$ & $13 \%$ & $18 \%$ & $18 \%$ \\
\hline 21:00:00 & $0 \%$ & $0 \%$ & $4 \%$ & $4 \%$ & $3 \%$ & $3 \%$ & $4 \%$ & $4 \%$ & $1 \%$ & $1 \%$ & $3 \%$ & $3 \%$ & $3 \%$ & $3 \%$ \\
\hline
\end{tabular}

Dari tabel 7. Menunjukkan bahwa persentase hasil prediksi (HP) sudah mendekati data real (DR) sehingga metode RNN berbasis LSTM telah berhasil memprediksi kepadatan restoran dengan optimal, serta parameter yang digunakan pada model dapat menghasilkan nilai MSE dengan selisih eror terkecil. Jika dibuat plotting perbandingan data real dengan prediksi adalah sebagai berikut:

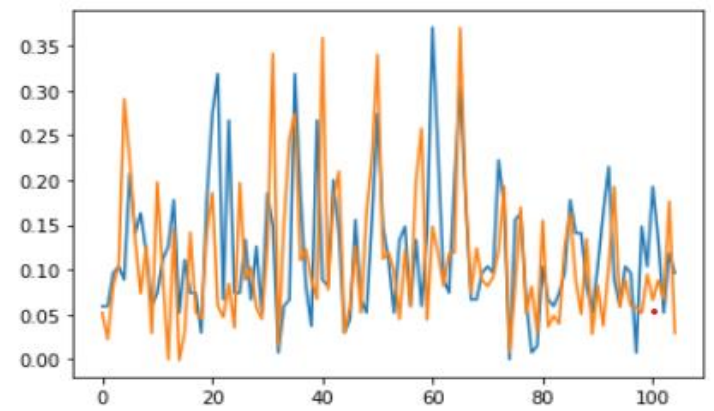

Gambar 2. plotting Perbandingan Data Real dengan Prediksi

Pada Gambar 2. Perbandingan data hasil prediksi (orange) dan data real (biru) menunjukkan model sudah baik dalam melakukan pembelajaran data karena plotting hasil prediksi sudah mengikuti pola pada data real. Dalam memprediksi kepadatan restoran dibuat rentang nilai tertentu untuk mengartikan keadaan restoran tersebut dalam kosong, sedang, penuh, atau sangat penuh. Rentang nilai dibuat dengan range $(0,0.5)$ karena jumlah maksimal pengunjung restoran rata-rata berada dibawah $50 \%$ saat mencapai kepadatan pada data real.

Tabel 8. Rentang Nilai Terhadap Kondisi Restoran

\begin{tabular}{cc}
\hline Rentang Nilai & Kondisi Restoran \\
\hline Output $<0.125$ & Kosong \\
$0.125>=$ Output $<0.25$ & Sedang \\
$0.25>=$ Output $<0.375$ & Penuh \\
$0.375>=$ Output $<0.50$ & Sangat Penuh \\
\hline
\end{tabular}

Selanjutnya hasil prediksi akan diklasifikasi sesuai dengan rentan nilai untuk memprediksi kondisi kepadatan suatu restoran. Adapun hasil klasifikasi data prediksi ditunjukkan pada tabel sebagai berikut: 
ISSN 2614-5278 (media cetak), ISSN 2548-8368 (media online)

Available Online at https://ejurnal.stmik-budidarma.ac.id/index.php/mib DOI 10.30865/mib.v5i2.2916

Tabel 9. Klasifikasi Prediksi Kepadatan Restoran

\begin{tabular}{cccccccc}
\hline Jam/Hari & Senin & Selasa & Rabu & Kamis & Jum'at & Sabtu & Minggu \\
\hline 07:00:00 & kosong & kosong & sedang & kosong & sedang & kosong & kosong \\
08:00:00 & kosong & sedang & penuh & sedang & kosong & sedang & kosong \\
09:00:00 & kosong & kosong & kosong & kosong & kosong & kosong & kosong \\
10:00:00 & kosong & kosong & sedang & sedang & kosong & kosong & sedang \\
11:00:00 & penuh & sedang & sedang & sedang & kosong & kosong & kosong \\
12:00:00 & sedang & sedang & penuh & penuh & penuh & sedang & kosong \\
13:00:00 & sedang & kosong & kosong & kosong & sedang & kosong & kosong \\
14:00:00 & kosong & kosong & sedang & kosong & kosong & kosong & kosong \\
15:00:00 & kosong & kosong & kosong & kosong & sedang & kosong & kosong \\
16:00:00 & kosong & kosong & kosong & kosong & kosong & sedang & kosong \\
17:00:00 & sedang & sedang & penuh & sedang & kosong & sedang & kosong \\
18:00:00 & kosong & kosong & kosong & kosong & kosong & kosong & kosong \\
19:00:00 & kosong & kosong & sedang & sedang & sedang & kosong & kosong \\
20:00:00 & sedang & kosong & sedang & penuh & sedang & sedang & sedang \\
21:00:00 & kosong & kosong & kosong & kosong & kosong & kosong & kosong \\
\hline
\end{tabular}

Setelah didapatkan hasil prediksi kepadatan restoran, dapat dihitung persentase kecocokan antara data hasil prediksi dengan data real di lapangan dengan hasil kecocokan sebesar $99 \%$.

\section{KESIMPULAN}

Setelah melakukan penelitian serta menganalisa hasil dari pengujian yang dilakukan, dapat disimpulan bahwa metode Recurrent Neural Network berbasis LSTM yang digunakan sangat optimal dalam memprediksi kepadatan restoran. Karena menghasilkan kecocokan dengan data di lapangan sebesar 99\%, dengan menguji beberapa parameter dapat menghasilkan nilai learning rate terbaik sebesar 0,001 dan maksimal epoch terbaik berada di nilai epoch ke 2000, dimana nilai MSE yang diperoleh hampir mendekati nol dengan nilai 2.78E-07 dengan MSE pada data uji sebesar 0.0069 .

\section{REFERENCES}

[1] D. Tuwu, "Kebijakan Pemerintah Dalam Penanganan Pandemi Covid-19," J. Publicuho, vol. 3, no. 2, p. 267, 2020, doi: 10.35817/jpu.v3i2.12535.

[2] E. Turban, E. McLean, and J. Wetherbe, Information Technology for Management: Transforming Organizations in the Digital Economy, 5th ed. Hoboke: John Wiley \& Sons, 2009.

[3] Herdianto, "Prediksi Kerusakan Motor Induksi Menggunakan Metode Jaringan Saraf Tiruan Backpropagation," Universitas Sumatera Utara, 2013.

[4] A. A. Rizal and S. Hartati, "PREDIKSI KUNJUNGAN WISATAWAN DENGAN RECURRENT NEURAL NETWORK EXTENDED KALMAN FILTER,” vol. X, no. 1, pp. 7-18, 2017.

[5] D. Kriesel, A Brief Introduction to neural networks. 2007.

[6] J. W. G. P. Putra, Pengenalan Konsep Pembelajaran Mesin dan Deep Learning, 1.2. Tokyo, 2018.

[7] A. Pulver and S. Lyu, "LSTM with working memory," Proc. Int. Jt. Conf. Neural Networks, vol. 2017-May, pp. 845851, 2017, doi: 10.1109/IJCNN.2017.7965940.

[8] C. Olah, "Understanding LSTM Network," 2015. http://colah.github.io/posts/2015-08-\%0AUnderstanding-LSTMs/.

[9] A. A. Rizal and S. Soraya, "Multi Time Steps Prediction Dengan Recurrent Neural," vol. 18, no. 1, pp. 115-124, 2018, doi: https://doi.org/10.30812/matrik.v18i1.344.

[10] R. Fu, Z. Zhang, and L. Li, "Using LSTM and GRU Neural Network Methods for Traffic Flow Prediction," 31st Youth Acad. Annu. Conf. Chinese Assoc. Autom., pp. 5-9, 2016, doi: 10.1109/YAC.2016.7804912.

[11] C. Christiani, P. Tedjo, and B. Martono, "ANALISIS DAMPAK KEPADATAN PENDUDUK TERHADAP KUALITAS HIDUP MASYARAKAT PROVINSI JAWA TENGAH,” J. Ilm. UNTAG Semarang, pp. 102-114.

[12] I. Bagoes and Mantra, Demografi Umum, Kedua. Yogyakarta: Pustaka Belajar, 2007.

[13] M. T. N. Thalib, "Kepadatan Arus Lalu Lintas Pada Ruas Jalan,” J. Perad. saIns, rekayAsa dan Teknol. Sekol. Tinggi Tek. Bina Taruna Gorontalo, vol. 6, no. 1, pp. 59-68.

[14] I. Afrianty, E. Humairah, S. Sanjaya, S. K. Gusti, and E. Rouza, "Penerapan Elman Recurrent Neural Network (ERNN) Untuk Prediksi Penjualan Pilus,” Semin. Nas. Teknol. Inf. Komun. dan Ind., vol. 0, no. 0, pp. 158-164, 2018, [Online] Available: http://ejournal.uin-suska.ac.id/index.php/SNTIKI/article/view/5964.

[15] L. Zhang and P. B. Luh, "Neural network-based market clearing price prediction and confidence interval estimation with an improved extended Kalman filter method," IEEE Trans. Power Syst., vol. 20, no. 1, pp. 59-66, 2005, doi: 10.1109/TPWRS.2004.840416.

[16] R. Adnan, F. A. Ruslan, A. M. Samad, and Z. M. Zain, "New Artificial Neural Network and Extended Kalman Filter hybrid model of flood prediction system," Proc. - 2013 IEEE 9th Int. Colloq. Signal Process. its Appl. CSPA 2013, pp. 252-257, 2013, doi: 10.1109/CSPA.2013.6530051.

[17] M. Kumar and A. Bala, "Analyzing Twitter sentiments through big data," 3rd Int. Conf. Comput. Sustain. Glob. Dev., 2016. 
JURNAL MEDIA INFORMATIKA BUDIDARMA

Volume 5, Nomor 2, April 2021, Page 524-531

ISSN 2614-5278 (media cetak), ISSN 2548-8368 (media online)

Available Online at https://ejurnal.stmik-budidarma.ac.id/index.php/mib

DOI 10.30865/mib.v5i2.2916

[18] M. K. Sandi, A. L. Prasasti, and M. W. Paryasto, "RESTAURANT DENSITY PREDICTION SYSTEM USING FEED FORWARD NEURAL NETWORK," J. Ris. Inform., vol. 3, no. 2, 2021, [Online]. Available: http://ejournal.kresnamediapublisher.com/index.php/jri/article/view/202/81. 